\title{
PILOT-STUDY AZ ISKOLAI ÉTTERMEK ÉTELEINEK KEDVELÉSE ÉS AZ ÉTTERMI SZOLGÁLTATÁS FONTOSABB TÉNYEZÓINEK VIZSGÁLATÁHOZ
}

PILOT-STUDY FOR THE INVESTIGATION OF SCHO
AND MAIN FACTORS OF RESTAURA
${ }^{1,4}$ TóTH, András
${ }^{2,3}$ ITTZÉS, András
${ }^{1}$ PELYHE, Liza
${ }^{4}$ ILLÉS, B. Csaba
${ }^{4}$ DUNAY, Anna
${ }^{1}$ BITTSÁNSZKY, András

\begin{abstract}
'InDeRe Élelmezéskutató és Innovációs Intézet Nonprofit Kft. (InDeRe Institute for Food System Research and Innovation Nonprofit Kft.), 1116 Budapest, Fehérvári út 132-144., e-mail: andras.toth@indere.hu

${ }^{2}$ Szent István Egyetem, Kertészettudományi Kar, Biometria és Agrárinformatika Tanszék (Szent István University, Faculty of Horticultural Science, Department of Biometrics and Agricultural Informatics), 1118 Budapest, Villányi út 29-43.

${ }^{3}$ Budapesti Gazdasági Egyetem, Kereskedelmi, Vendéglátóipari és Idegenforgalmi Kar, Módszertani Intézeti Tanszéki Osztály

(Budapest Business School, Faculty of Commerce, Catering and Tourism, Institute of Methodology), 1054 Budapest, Alkotmány u. 9-11.

${ }^{4}$ Szent István Egyetem, Gazdaság és Társadalomtudományi Kar, Üzleti Tudományok Intézete, Vállalatgazdasági és Menedzsment Tanszék

(Szent István University, Faculty of Economics and Social Sciences, Institute of Business Studies, Department of Business Economics and Management), 2100 Gödöllő, Páter Károly utca 1.
\end{abstract}

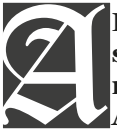

In Hungarian public educational institutions (nurseries, kindergartens, primary and secondary schools) it is compulsory to provide food for schoolchildren at least by one meal per day. Schoolchildren represented 14\% of the total population of Hungary in 2016. Although school catering is compulsory task for educational institutions, many students refuse this service, because of food intolerances or based on external reasons such as „I don't like', "it is not tasty" or because of negative opinions and rumours about school catering services. Surveys have already been conducted in some countries on the acceptance of school catering services in order to explore the reasons of the negative experiences, but in Hungary, our research was the first in this topic. Our main goal was to explore the acceptance level of the school catering services and their meals in the sample of schools in Budapest. The first step of our research was to launch a pilot study, where 202 students and teachers of five schools in Budapest filled a questionnaire. The most preferred meals of the students were roasted and fried meats (they would like to have these meals more frequently), and cakes/desserts. The least preferred meals were pottage, and simple soups, which they would like to consume less frequently. Teachers preferred healthier food, e.g. fish, stewed or grilled vegetables. In almost half of the different meal types, a significant difference was detected between the answers of teachers and students. Noodle dishes, cakes and desserts were preferred at significantly higher level by the students. The different characteristics of the meals (taste, aroma, nutritional value, temperature, serving style) were assessed as significantly less important by the students than by teachers. Food hygiene, healthy food and diversity of meals were assessed equally well by the two respondent groups. Both respondent groups indicated that adapting to the individual needs of the consumers is inadequate.

KuLCSSZAVAK: iskolai étkeztetés, menzai ételek kedveltsége, diákok és tanárok
KEYWORDS: school catering services, school meal preference in Hungary, students and teachers

JEL-KóD (JEL CODE): D12, L83

Az EMBERI ERŐFORRÁSOK MINISZTÉRIUMA ÚNKP-17-3 KóDSZÁMÚ ÚJ NEMZETI KIVÁLÓSÁG

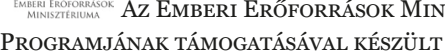




\section{BEVEZETÉS - INTRODUCTION}

Az iskolai étkeztetésre manapság igen komoly figyelem irányul ugyanis a gyermekek idejük nagy részét oktatási intézményekben töltik ezért a napi tápanyagmennyiség jelentős részét itt veszik magukhoz. A vonatkozó rendelet szerint a nevelési-oktatási intézményekben a közétkeztetés köteles a napi egyszeri étkezés szolgáltatása esetén az előírt napi energiaszükséglet 35\%-át egy ebéddel biztosítani (EMMI, 2014; EMMI, 2016; OGYÉI, 2016).

Magyarországon 6 éves kortól kezdik meg iskolai tanulmányaikat a gyermekek és általában 19 éves korukban fejezik be (EACEA, 2016). Ez a 2016-os adatok szerint 1384141 gyermeket érint Magyarországon, ami a népesség 14\%-a (KSH, 2016). Az iskolai étkeztetést ellátó helyek felében tálalókonyha üzemel ahol ételkészítés nem történik, az egységek ${ }^{1 / 3}$-a fözőkonyhaként üzemel, míg az oktatási intézmények 19\%-ában egyáltalán nincs múködő konyha. Az OÉTI 2013-as felmérése szerint a 7-18 éves korosztály $61 \%$-a vette igénybe a diákéttermi szolgáltatást. Ez az arány az alsó tagozatban a legnagyobb (87\%), az 5-8. évfolyamokon 63\%, 9-12. évfolyamokon a legalacsonyabb, 27\% (BAKACS et al., 2014).

Magyarországon az összes oktatási intézménybe járó gyermek étkeztetése biztosított, jóllehet nem minden gyermek veszi igénybe az étkeztetési szolgáltatást. Az sem biztos azonban, hogy aki megrendelte az ételt az étkezett-e egyáltalán és az sem, hogy aki étkezett, az megette-e a kapott ételt. Az ételt gyakran egyszerú szeretem/nem szeretem, finom/nem finom kellemetlenség miatt hagyják a tányéron. Ahhoz, hogy az iskolai étkeztetés során keletkező hulladékok mennyiségét csökkentsük, elengedhetetlen, hogy a tanulók számára vonzó és kedvelt ételeket biztosítsunk. A „nem szeretem”, „nem finom" kellemetlenségek megismeréséhez célszerü felmérést végeznünk a tanulók körében az iskolában felszolgált ételek kedveltségéről, preferenciájáról. A vonatkozó szakirodalomban számos módszert találunk, amelyekben többnyire különböző tesztekkel számszerüsítik egy termék kedveltségének fokozatait (ANDERSEN et al., 2016; PAGLIARINI, GABBIADINI és RATTI, 2005; TUORILA et al., 2015; ASTM, 1998; POPPER, 2004; ASTM, 2004).
Hosszú távú célul tűztük ki, hogy felmérjük budapesti iskolákban felszolgált ételek kedveltségét és a diákéttermi szolgáltatás fontosabb tényezőinek vizsgálatát. Sajnos sok diák és szülő kipróbálás nélkül is negatívan értékeli a diákéttermet, csupán az általános rossz hírnév és szájhagyomány útján terjedő információk miatt. Vizsgálatunkkal nekik is szeretnénk hiteles információkat nyújtani a budapesti iskolai étkeztetés fogyasztói megítéléséről, minőségéről.

Ennek a nagyszabású tanulmánynak az első lépése az e cikkben közölt „pilot-study”, vagyis előzetes-vizsgálat, amiben célul tűztük ki, hogy az iskolai étkeztetés fontosabb tényezőire vonatkozó kérdőívet dolgozzunk ki és teszteljünk.

\section{ANYAg ÉS MÓDSZER - MATERIALS} AND METHODS

\subsection{A kérdőív összeállítása - Compilation of the Questionnaire}

A kérdőív összeállításához a hazai és nemzetközi szakirodalmat vettük alapul, valamint figyelembe vettük az iskolai konyhákat müködtető szervezetek információigényét is. Az iskolai étkeztetés során általában felszolgált ételeket 18 csoportba soroltuk be. A kérdőív anonim volt, a kitöltő személy életkorára, nemére, és iskolai foglalkozására (diák/pedagógus/iskolai dolgozó) kérdeztünk rá.

\subsection{A felmérés helyszínei - The Locations of the Questionnaire Survey}

A kérdőív kitöltése öt budapesti középiskolában történt, öt különböző napon. A kérdőív nem az aznapi ételre/ételekre vonatkozott, ezért nem feltétele az azonos napi kitöltés. Az öt iskolában tálalókonyha müködött, egyazon beszállítóval szerződtek, ezért az ételek minősége az összes vizsgált konyhában azonos volt.

\subsection{Kérdőíves felmérés - Questionnaire Procedure}

Az ebédelés ideje az iskolákban 10:00-től 14:0o-ig tartott. Az ebédelés néhol 1-3 szünetben zajlott, máshol folyamatos volt az ételkia- 
dás időtartománya alatt. A résztvevők a tesztet étkezésük közben töltötték ki. A teszt kitöltése nem volt kötelező.

\subsection{A kérdőívet kitöltő személyek - The Surveyed Persons}

Az öt iskolában 167 diák, 35 pedagógus (öszszesen 202 személy) töltötte ki a kérdőívet. A diákok életkora 15-23 ebból 68 lány és 95 fiú a 4-en nem jelölték a nemüket. A pedagógusok életkora 22-67 év közé esett közülük 20 volt nő és 15 férfi.

\subsection{Az adatok elemzése - Data Analysis}

Az eredményeket az IBM SPSS Statistics (Version 22) szoftverrel értékeltük ki. A preferencia vizsgálatoknál meghatároztuk a kedveltségi fokozatok átlagát és szórását (hiányzó adatnak véve a „nem tudom” és az üres rubrikákat), továbbá e két értékből számolva a variációs koefficienst. Ez az érték a minta relatív szórása. Minél kisebb, annál homogénebb a minta, azaz esetünkben annál egybehangzóbb az adott ételre, ételcsoportra a vélemény. Egybehangzónak o,20 érték alatt, o,20 és 0,30 között átmenetinek, o,30 felett megosztottnak tekintettük a véleményeket.

A diákok és a pedagógusok preferenciájának összehasonlításához Mann-Whitney-próbát használtunk, ami a kétmintás t-próba nem parametrikus megfelelője. A szignifikancia szintet $5 \%$-ban $(\mathrm{p}=0,05)$ határoztuk meg.

\section{EREDméNyek - Results}

\subsection{A kérdőív összeállítása - Compilation of the Questionnaire}

A kérdőív összeállítása előtt több nemzetközi példát szemléztünk. Dánia egyik városában 9 iskolában összesen 834 fő 8-11 éves iskolást kérdeztek meg 5 pontos smiley skálán (nagyon rossz - rossz - se nem rossz se nem jó - jó nagyon jó), egy az iskolában bevezetésre kerülő új típusú menüről (ANDERSEN et al., 2016). Olaszország egyik városában, 120 fő 7-10 éves azonos iskolába járó tanulótól kérdezték meg az iskolai menük kedveltségét egy 7 fokozatú élvezeti skálán (PAGLIARINI, GABBIADINI és RATTI, 2005). Egy finn felmérésben 127 fó 8-15 éves helsinki iskolai tanuló vett részt, ahol ételek kedveltsége mellett további információkra is kíváncsiak voltak, úgymint (TUORILA et al., 2015):

- Ételválasztás (általános, vegetáriánus, nem ettem)

- Étel kedvelése (7 pontos élvezeti skála: $1=$ nagyon rossz, $7=$ nagyon jó)

- Éhségérzet az étkezés megkezdése előtt (7 pontos intenzitás skála: 1=egyáltalán nem, 7=nagyon éhes; vagy „nem mondom meg")

- Reakció a napi menü elolvasásakor (7 lehetőség: feldobódott, dühös, szomorú, elégedett, csalódott, boldog, semmi)

- Általános étkezési élmény (7 pontos élvezeti skála: $1=$ nagyon rossz, $2=$ inkább rossz, 3=egy kicsit rossz, 4=se nem jó, se nem rossz, $5=$ =egy kicsit jó, 6=inkább jó, $7=$ nagyon jó)

- Főétel milyensége (7 pontos élvezeti skála: 1=nagyon rossz, 7=nagyon jó)

- Fő́tel tulajdonságai

- Hőmérséklet (7 pontos optimum skála: 1=túlságosan hideg/, 4=éppen megfelelő, 7=túlságosan meleg)

- Füszerezettség (7 pontos optimum skála: 1=túlságosan füszerezetlen, 4=éppen megfelelő, $7=$ túlságosan füszeres)

- Sósság (7 pontos optimum skála: $1=$ túlságosan sótlan, 4=éppen megfelelő, $7=$ túlságosan sós)

- Saláta és a kenyér milyensége (7 pontos élvezeti skála: $1=$ nagyon rossz, $7=$ nagyon jó; vagy „nem evett”)

- Innivaló választás (tej, savanyú tej, víz, semmi)

- Jó vagy rossz étel megnevezése, ami minden nap szerepelt (Nyitott végű kérdés.)

- Zaj az étkezőben (7 pontos optimum skála: 1=túlságosan csendes; 4=éppen megfelelő, 7=túlságosan zajos)

- Sor előrehaladása (7 pontos optimum skála: 1 =túlságosan lassú; 4=éppen megfelelő, $7=$ túlságosan gyors)

- Ebédidő ütemezése (7 pontos optimum skála: 1=túlságosan korai; 4=éppen megfelelő, 7=túlságosan kései)

- A kiszolgáló személyzet kedvessége (7 
pontos intenzitás skála: 1=nem kedves, $7=$ nagyon kedves)

- 10 neofóbiára vonatkozó kérdés (7 pontos élvezeti skála: $1=$ egyáltalán nem értek egyet, $7=$ =teljesen egyetértek)

Utóbbi tanulmányban látható, hogy a feltett kérdések nem csak az ételre/ételcsoportra vonatkozhatnak, hanem az egyén belső folyamataira (pl. éhségérzet, reakció a menü láttán) és a külső környezetre (pl. zaj, kiszolgáló személyzet) is, így átfogó képet kaphatunk a menza „élményéról”.

A fenti példákat a hazai sajátosságokat és konyhákat üzemeltető szervezetek információigényeit figyelembe véve a kérdőívünk az alábbiakat tartalmazta:

- Ételek, ételcsoportok kedveltsége 5 pontos hedonikus skálán ( $1=$ egyáltalán nem kedveli, 5=nagyon kedveli) + „nem tudom" alkalmazásával:

- Egyszerü levesek

- Húsos levesek

- Gyümölcslevesek

- Főzelékek

- Párolt, grillezett, rántott zöldségek

- Pörköltek, ragus és szószos ételek

- Paradicsomos, paradicsom szószos ételek

- Tejszínes, tejes ételek

- Rakott ételek

- Sült húsok

- Rántott húsok

- Halak

- Tészta ételek

- Majonézes saláták

- Zöld salátafélék

- Savanyúságok

- Gyümölcsök

- Sütemények, desszertek

- Három-három többször és kevesebbszer fogyasztandó étel megnevezése nyitott kérdésben. A megnevezett ételeket a fentebb felsorolt kategóriákba soroltuk kiegészítve a „Gabona köret”, „Tészta köret”, „Belsőség”, „Gomba” és „Burgonya köret” kategóriákkal.

- Az iskolai étkeztetés legfontosabb tényezőinek rangsorolása 9 pontos intenzitás teszttel (1=legfontosabb, 9=legkevésbé fontos). A legfontosabb tényezők:
- Jó ízü, ízletes

- Jó, kellemes illatú

- Tápláló

- Egészséges

- Megfelelő hőmérsékletű

- Változatos

- Higiénikus (tiszta evőeszközök és asztal)

- Egyéni igényekhez (diétákhoz) igazodó

- Szépen tálalt

- Az előző pontban felsorolt iskolai étkeztetés legfontosabb tényezői megvalósulásának értékelése 5 pontos intenzitás skálán (1=egyáltalán nem jellemző, $5=$ =nagyon jellemző).

- További kérdéseket a kitöltő nemére, korára, státuszára (diák, pedagógus, dolgozó), testalkatára valamint általános étvágyára vonatkoztak.

\subsection{A kérdőív alkalmazása - Application of Questionnaire}

\subsubsection{Menza ételek kedveltsége-Preference of School Meals}

A diákok nagyon kedvelték a rántott húsokat (68\%), süteményeket, desszerteket (66\%) és a sült húsokat (59\%). A kedvelési fokozatok átlagait figyelembe véve is ez a három étel, ételcsoport áll a kedvelési skála első három helyén (1. táblázat).

Kimagaslóan nem kedvelt ételt/ételcsoportot nem jelöltek meg a diákok. Megosztott véleménnyel a főzelékek és az egyszerü levesek zárják a kedvelt ételek listáját, mindkettő ételcsoport a "kedveli is meg nem is” kategóriába tartozik.

A pedagógusok egybehangzóan, 60\% feletti aránnyal nagyon kedvelték a halakat (74\%), rántott húsokat (71\%), párolt, grillezett, rántott zöldségeket (69\%) és sült húsokat (63\%) (1. táblázat). Kimagaslóan nem kedvelt és „kedveli is meg nem is" ételt/ételcsoportot nem jelöltek meg, úgyhogy az ételkedvelési listájuk végén is kedvelt ételek/ételcsoportok állnak, úgymint tészta ételek (31\%) és egyszerű levesek (34\%).

Összehasonlítva a diákok és pedagógusok ételpreferenciáját, a tanárok jobban kedvelték 
a húsos leveseket, fózelékeket, párolt, grillezett, rántott zöldségeket, pörkölteket, ragus és szószos ételeket, rakott ételeket, halakat, zöld salátaféléket és savanyúságokat. A diákok vi- szont a tészta ételeket és a süteményeket, deszszerteket kedvelték statisztikailag igazolható módon jobban.

\section{TÁBLÁZAT}

TABLE 1

Diákétteremben felszolgált ételcsoportok kedveltsége az ételekre adott átlag pontszámuk alapján diákok és pedagógusok szerint

(Students' and Teachers' Preference of School Meals Based on the Average Points of Preference)

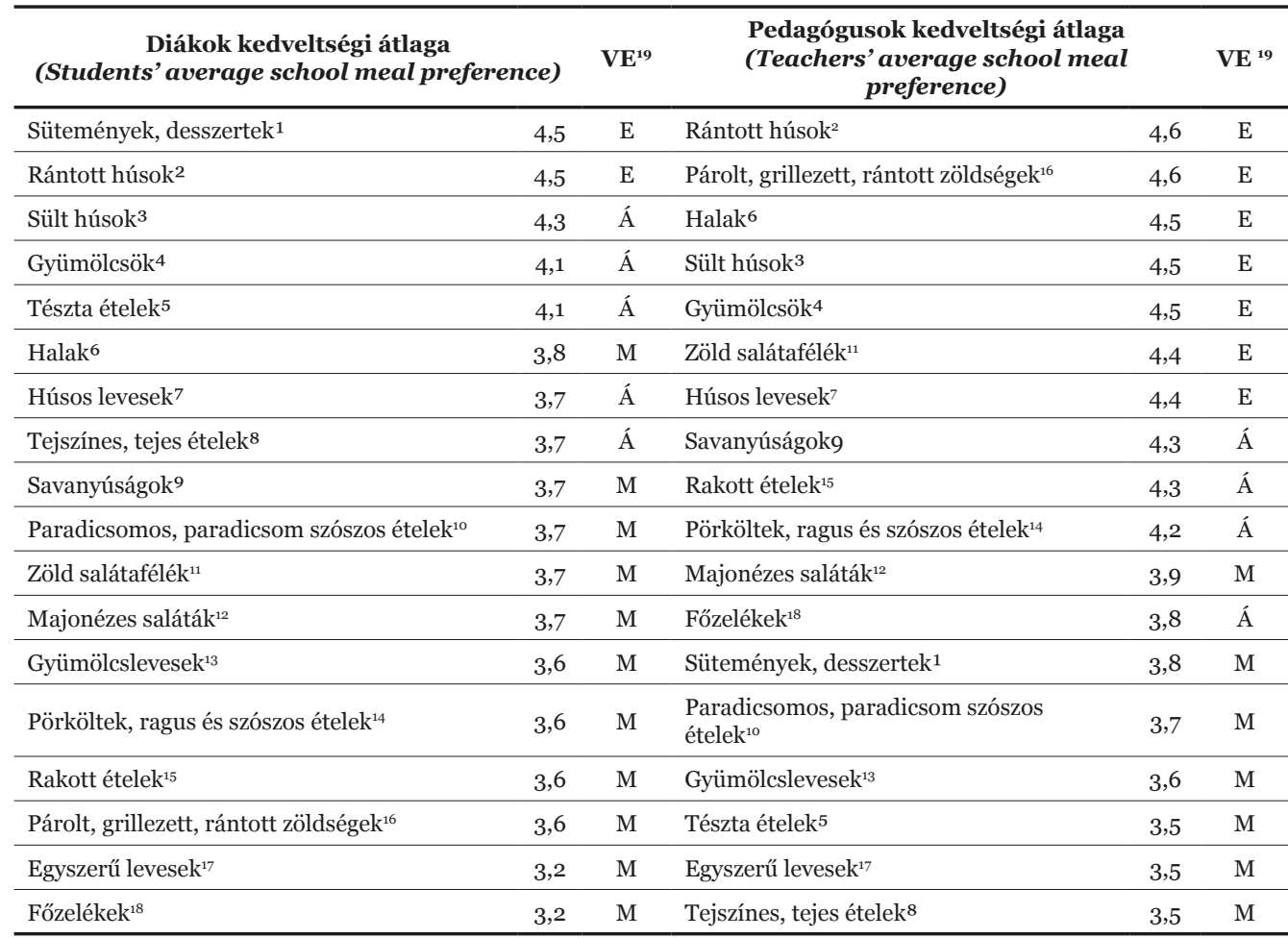

${ }^{1}$ Cakes, desserts; ${ }^{2}$ Fried meats; ${ }^{3}$ Roasted meats; ${ }^{4}$ Fruits; ${ }^{5}$ Noodle dishes; 6 Fishes; ${ }^{7}$ Soups with meat; 8 Meals with cream or milk; ${ }^{9}$ Pickles; ${ }^{10}$ Meals with tomato, tomato sauce; ${ }^{11}$ Green salads; ${ }^{12}$ Mayonnaise salads; ${ }^{13}$ Fruit soups; ${ }^{14}$ Stew, ragout and meals with sauce; ${ }^{15}$ Stuffed meals; ${ }^{16}$ Stewed, grilled, fried vegetables; ${ }^{17}$ Simple soups; ${ }^{18}$ Pottages

${ }^{19} \mathrm{VE}$ : élemény egységessége (Unity of opinion): E: egybehangzó (concordant); Á: átmeneti (transitional); M: megosztott (divided)

Forrás (Source): Saját kutatás (Own research)

3.2.2. Három-három többször, kevesebbszer fogyasztandó étel - Three-three School Meals Which Would Be Eaten More or Less

A diákok sürübben fogyasztanának sült húst, rántott húst és paradicsomos, paradicsom szószos ételeket, míg a pedagógusok pörkölteket, ragus és szószos ételeket, sült húsokat, húsos leveseket, és halakat (1. ábra).

Kevesebbszer ennének főzeléket, és gabona köretet a diákok és a pedagógusok is. A diákok továbbá kevesebbszer fogyasztanának az egyszerű levesekből, a pedagógusok pedig a tészta ételekből (1. ábra). 
Tóth A. - Ittzzés A. - Pelyhe L. - Illés B. Cs. - Dunay A. - Bittsánsziky A.

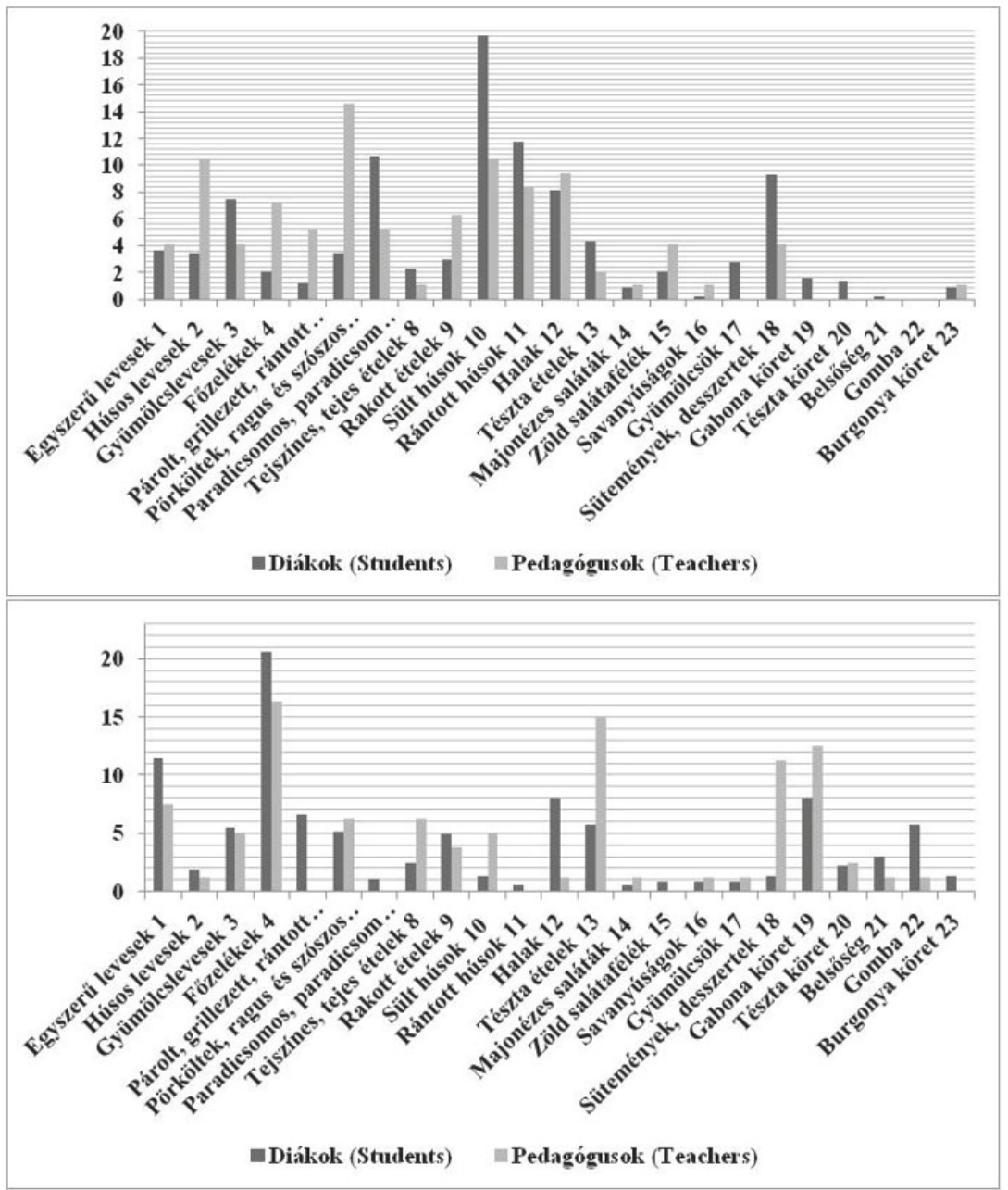

\section{1. ÁBRA}

Többször (felső) illetve kevesebbszer (alsó) fogyasztandó ételcsoportok,\%

FIG. 1 (Food Groups to Be Consumed More (above) or Less (under), \%)

${ }^{1}$ Simple soups; ${ }^{2}$ Soups with meat; ${ }^{3}$ Fruit soups; ${ }^{4}$ Pottages; 5 Párolt, grillezett, rántott zöldségek (Stewed, grilled, fried vegetables); ${ }^{6}$ Pörköltek, ragus és szószos ételek (Stew, ragout and meals with sauce); ${ }^{7}$ Paradicsomos, paradicsom szószos ételek (Meals with tomato, tomato sauce); ${ }^{8}$ Meals with cream or milk; ${ }^{9}$ Stuffed meals; ${ }^{10}$ Roasted meats; ${ }^{11}$ Fried meats;

${ }^{12}$ Fishes; ${ }^{13}$ Noodle dishes; ${ }^{14}$ Mayonnaise salads; ${ }^{15}$ Green salads; ${ }^{16}$ Pickles; ${ }^{17}$ Fruits; ${ }^{18}$ Cakes,desserts; ${ }^{19}$ Stuffed meals;

${ }^{20}$ Noodle garnish; ${ }^{21}$ Harslet; ${ }^{22}$ Mushroom; ${ }^{23}$ Potato garnish

Forrás (Source): Saját kutatás (Own research) 


\subsubsection{A menza legfontosabb tényezői és megvalósulásuk - The Most Important Factors of the School Lunch and Their Realisation}

Az iskolai ételfogyasztáshoz kapcsolódó legfontosabb tényezők rangsorolásának felmérése nem adott értékelhető eredményt, mert a megkérdezettek nem rangsorolásként értelmezték a feladatot, ezért a kérdőívből a kérdéscsoportot eltávolítottuk. Itt csak a legfontosabb tényezők megvalósulását vizsgáltuk.

A diákok többsége az ételek jó ízére és kellemes illatára vonatkozóan a „jellemző is meg nem is" kategóriát jelölte meg (2. ábra). Táplálóságuk átmeneti véleményt adott a ,jellemző és a jellemző is meg nem is" között. Jellemzően egészségesnek, és változatosnak, megfelelő hőmérsékletűnek találták az ételeket, viszont szépen találásukat közepesre értékelték. A higiénikusságot nagyon jellemzőre értékelték. Az egyéni igényekhez való igazodásról a vélemény erősen megoszlott és a közepesról az egyáltalán nem jellemző felé tendál (2. ábra).

Pedagógusok szerint jellemző az ételek jó íze, illata, táplálósága, egészségessége, hőmérséklete és változatossága. A higiénia szerintük „jellemző” - „nagyon jellemző”. Az ételek szépen tálalása inkább „,jellemző”, vagy a „jellemező is meg nem is" fele tendál. A higiénikusságot nagyon jellemzőre értékelték. Az egyéni igényekhez való igazodásról a vélemény a diákokéhoz hasonlóan erősen megoszlott és a közepesről az egyáltalán nem jellemző felé tendál (2. ábra).

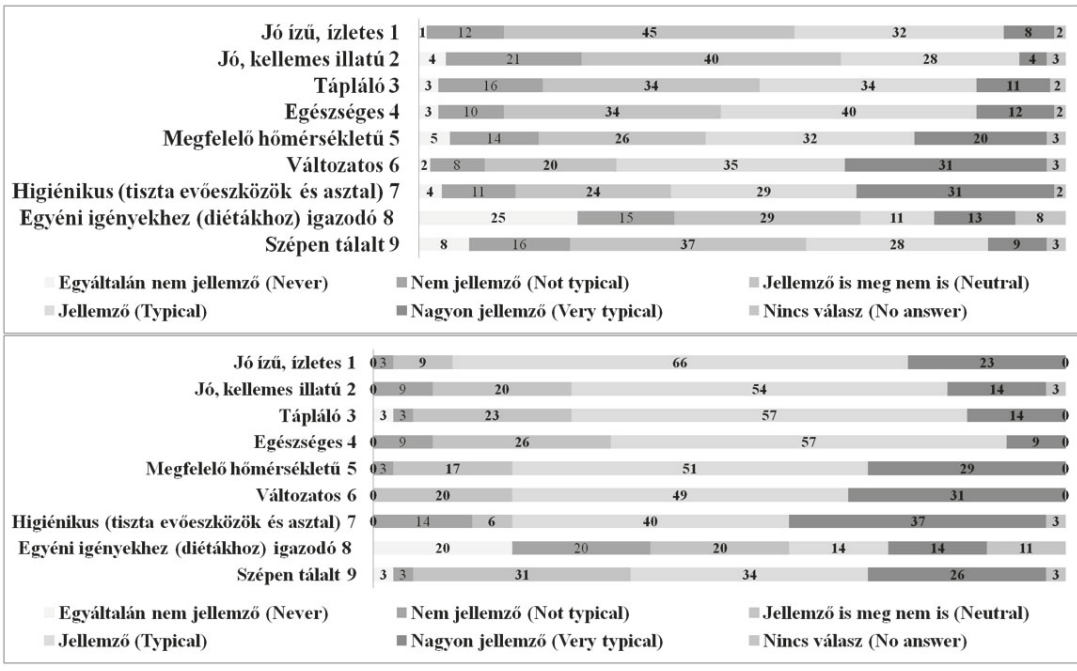

2. ÁBRA

\section{Az iskolai ételfogyasztás legfontosabb tényezőinek megvalósulása a diákok (felsó) és pedagógusok (alsó) szerint, \% \\ (The Realisation of the School Lunch's Most Important Factors by Students (above) and Teachers (under), \%)}

${ }^{1}$ Good taste; ${ }^{2}$ Good aroma; ${ }^{3}$ Nutritional value; ${ }^{4}$ Healthy; ${ }^{5}$ Temperature; ${ }^{6}$ Diversity; ${ }^{7}$ Hygienic; 8 Meets the individual needs; ${ }^{9}$ Serving style

Forrás (Source): Saját kutatás (Own research) 
A pedagógusok minden esetben kedvezőbben ítélték meg az adott tényezőt, mint a diákok (3. ábra). Ez szignifikánsan nagyobb volt az ételek íze $(\mathrm{p}=0,00)$, illata $(\mathrm{p}=0,00)$, táplálósága $(\mathrm{p}=0,01)$, hőmérséklete $(\mathrm{p}=0,01)$, és szépen tálalása $(\mathrm{p}=0,00)$ esetében.

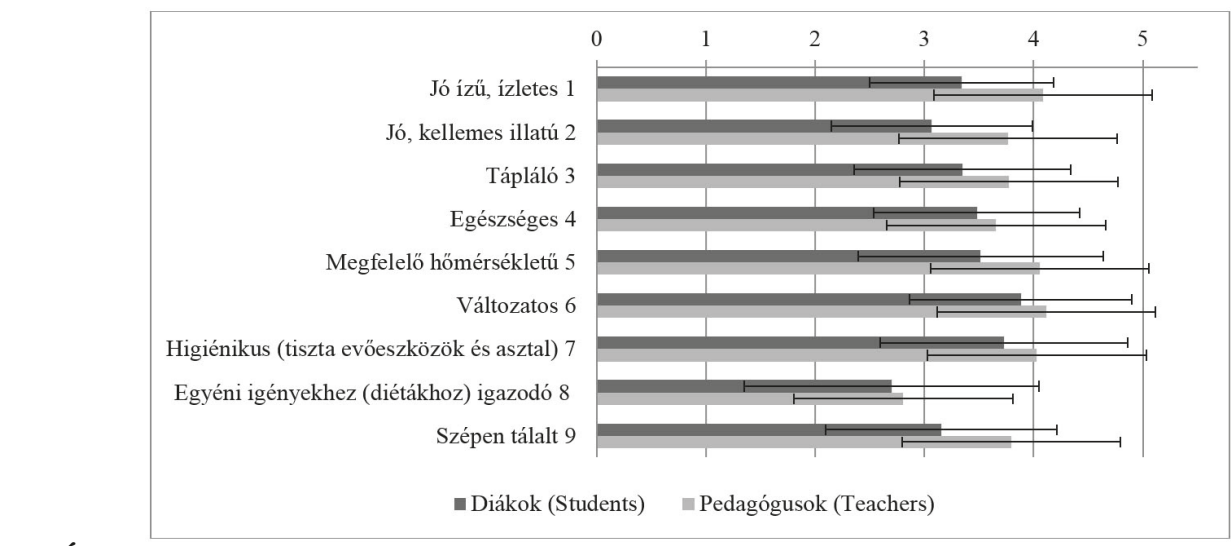

3. ÁBRA

FIG. 3

Az iskolai ételfogyasztás legfontosabb tényezőinek megvalósulásának összehasonlítása a diákok és a pedagógusok szerint

(The Realisation of the School Lunch's Most Important Factors by Students and Teachers) ${ }^{2}$ Good taste; ${ }^{2}$ Good aroma; ${ }^{3}$ Nutritional value; ${ }^{4}$ Healthy; ${ }^{5}$ Temperature; ${ }^{6}$ Diversity; ${ }^{7}$ Hygienic; 8 Meets the individual needs; ${ }^{9}$ Serving style

Forrás (Source): Saját kutatás (Own research)

\section{4. ÉRTÉKELÉS ÉS \\ KÖVETKEZTETÉSEK - DiSCUSSION AND CONCLUSIONS}

Tesztünket 167 diák és 35 tanár töltötte ki. A kitöltő személlyel kapcsolatos kérdések és válaszok többségükben egyértelmúek voltak mind a kitöltő személynek, mind a kiértékelő személynek. A „menza legfontosabb tényezőinek rangsorolása” témakörünk felmérése nem sikerült, ugyanis kérésünk félreérthetőre sikerült. Mi azt szerettük volna, hogy sorrendbe tegyék a kilenc tényezőt fontosságuk szerint (első helyre a legfontosabbat helyezzék). Azonban mind a diákok mind a pedagógusok egyenként osztályozták a tényezőket 1-9-ig. Ezeket az eredményeket nem értékeltük ki valamint a kérdéscsoportot a kérdőívből eltávolítottuk.

A diákéttermi ételek kedveltségének meghatározása nem okozott problémát; a diákok esetében a rubrikák o,8\%-ába került „nem tudom” válasz (pedagógusok esetében ez o\%), és o,5\%-ába semmilyen válasz (pedagógusok esetében ez 1\%).

A „melyik három ételből szeretne többet, illetve kevesebbet fogyasztani” nyitott kérdésre a diákok esetében a rubrikák $2 \%$ és $5 \%$-a, pedagógusok esetében $9 \%$ és $23 \%$-a maradt üresen. A „menza legfontosabb tényezőinek megvalósulása" témakör válaszadásaival sem volt probléma, a diákoknál csak 3\%-ban, a pedagógusoknál 2\%-ban nem volt válasz.

A pilot teszt elvégzése után a kérdőív alkalmassá vált nagy mintaszámú felmérések elvégzésére is.

A jelenlegi kérdőíves felmérésből az alábbi eredmények szürhetők le.

A diákok nagyon kedvelt ételei közé a húsok tartoznak (sült illetve rántott hús), amiket nem lehet elrontani, illetve a sütemények és desszertek, amelyek ugyan egészségtelen ételcsoportok, de láthatólag ez a szempont háttérbe szorul. Egyöntetüen nem kedvelt ételt/ ételcsoportot nem jelöltek meg a diákok, de a kedveltségi listájuk végén a fözelékek és az egyszerü levesek álltak. Véleményük, megosztott volt a kedveltségi lista nagy részében, viszont a kedvelt ételeknél egybehangzó, illetve átmeneti a kedvelt és a nagyon kedvelt fokozat között. A pedagógusok egészségesebb ételcsoportokat 
preferáltak, úgymint a halak, és a párolt, grillezett, rántott zöldségek, de a diákokkal egyezően náluk is kedvelt a rántott és a sült hús. Listájuk végén a tészta ételek, illetve a diákok véleményével egyezően az egyszerú levesek álltak. Az ő véleményük nagyobb mértékben volt egybehangzó (inkább az életkoruk, kevésbé válogatósságuk mintsem a válaszolók kisebb száma miatt), mint a diákok esetében. Általában a pedagógusok magasabb értékelési szintet adtak egy-egy ételcsoportra, ezért az ételcsoportok majdnem felénél szignifikáns különbség adódik a diákok válaszaihoz képest. Viszont a sok szénhidrátot tartalmazó ételeket (tészta ételek, sütemények, desszertek) a diákok kedvelték szignifikánsabban jobban, ami különbség valószínúleg a pedagógusok tudatosabb, egészségesebb táplálkozásának köszönhető.

A diákok a kedvenc ételcsoportjai közül kettőt fogyasztanának többször (sült húsok, rántott húsok), továbbá a kedveltségi skálán megosztott véleményt kapó paradicsomos, paradicsom szószos ételeket is. A pedagógusok az egybehangzóan nagyon kedvelt ételek közül ennének többször (halak, sült hús, húsos leves) és egy kedvelt-nagyon kedvelt átmenetiből (pörkölteket, ragus és szószos ételek). Mind a diákok mind a pedagógusok a nagyon kedvelt ételeik közül ennének többször, ráadásul a választott ételeik fehérje források, és előnyük, hogy kevés gyorsan felszívódó szénhidrátot tartalmaznak. Mindkét csoport kevesebbszer enne főzeléket és gabona köretet, aminek oka lehet, a nem a megfelelő, ízlésnek való elkészítés (a pedagógusok/felnőttek általában szeretik a fózelékeket és nyitottak a reform konyhára is), illetve diákok esetében az új ízvilág, vagy egyszerüen az ételpreferencia.

Megállapítható, hogy ha a menüben van sült és/vagy rántott hús, akkor az a fogás biztos, hogy kelendő lesz. A főzelékek és gabona köretek esetében fordított a helyzet, abból nem szükséges sokszor tálalni, mert a diákok, és a pedagógusok is keveset ennének belóle.

Az ételek tulajdonságainak (íz, illat, táplálóság, hőmérséklet, szépen tálalás) diákok sze- rinti minősítése szignifikánsan alacsonyabb a pedagógusokénál, ami lehet, hogy az életkori sajátosságokra (pl. finnyásság, kamaszkor) vezethető vissza. A higiéniával mindkét csoport meg volt elégedve. Szintén mindkét csoport jellemzően egészségesnek, és változatosnak találta az ételeket. A menza egyéni igényekhez való alkalmazkodása még nem megfelelő a diákok, sem a tanárok szerint.

Irodalmi adatok szerint a vevő elégedettséget az étel minőségén túlmenően befolyásolja az "atmoszféra" és a kiszolgálás (LÜLFS-BADEN, ROJAS-MÉNDEZ, és SPILLER, 2008).

Olaszországban végzett kérdőíves vizsgálat során az ételek ízletességére és az étkezés kellemessége volt a két fó vizsgált változó. Azokban az iskolákban ahol az ételek előállítási költsége magasabb volt, ott elégedettebbek voltak a szolgáltatással a diákok. Továbbá kimutatták, hogy az elégedettséggel negatív kapcsolatot mutatott az ételt szállító cég mérete (MAIETTA és GORGITANO, 2016).

Egy brit kutatás azt is megvizsgálta középiskolai diákok körében, hogy egy ételcsoport kedvelésének illetve elutasításának melyek lehetnek az indokai, mint pl. megjelenés, textúra, íz, illat, egészségesség, stb. (NOBLE et al., 2003).

A kérdőíves kutatással azonban nem lehet teljes körü képet kapni a kedveltségről és az elégedettségről ugyanis, a kérdőív kitöltése nem kötelező illetve a válaszadók nem feltétlenül azt írják be, amit valójában gondolnak. Továbbá alsóbb évfolyamokon a kérdőíves kutatás nem alkalmazható. Ezért további kiegészító vizsgálatok, mint például az el nem fogyasztott ételek mennyiségének felmérése javíthatná a felmérés színvonalát.

Összegezve tapasztalatainkat további célunk a kérdőív egyszerüsítése (pl. a rangsorolásos kérdés elvetése) és bővítése további kérdésekkel (pl. éhségérzet az étkezés megkezdése előtt), további iskolák, így több diák és pedagógus bevonása a kérdőíves felmérésekbe, hogy összképet kapjunk a budapesti iskolák menzájáról és ételeinek kedveléséről. 


\section{5. ÖSSZEFOGLALÁs - SUMMARY}

Magyarországon a nevelési-oktatási intézményekben a fenntartó köteles napi egyszeri étkezés keretében egy ebédet biztosítani. Ez iskoláskorú gyermekeknél a lakosság 14\%-át érinti (2016-os adat). Az iskolai étkeztetési szolgáltatást azonban sok tanuló nem veszi igénybe többnyire ételintolerancia, vagy „nem szeretem”, „nem finom”, és „negatív szóbeszéd a menzáról”, stb. okok miatt. Néhány országban már végeztek felméréseket az iskolai menza és ételei kedveléséről, hogy áthidaljanak ezek közül néhány okot.

Magyarországon még nem történt ilyen felmérés, ezért fó célunk a budapesti iskolai éttermek és ételeinek kedveltségi szintjének felmérése. Ennek első lépése e pilot-study, ahol az általunk kidolgozott menzaértékelő kérdőívet teszteltük öt iskola, összesen 202 étkező diákján és pedagógusán. Célul tűztük ki az iskolai étterem ételeire és fontosabb tényezőire vonatkozó kérdőívünk érthetőségének tesztelését továbbá kis csoportos vizsgálatát az ételek kedvelésének, és többször-kevesebbszer fogyasztásának, a szolgáltatás fontosabb tényezőinek rangsorolását és megvalósulását, illetve a diákok és pedagógusok véleményeinek összehasonlítását.

A kérdőívek kiértékeléséből megállapítottuk, hogy rangsorolásos kérdést nem érdemes beletenni a kérdőívbe. E kérdés kivételével kérdőívünk alkalmasnak bizonyult nagy mintaszámon való alkalmazásra. A kiértékelés során külön érdemes kiértékelni a diákok és pedagógusok válaszait az életkori sajátosságokból fakadó eltérések miatt.

A diákok nagyon kedvelt ételei közé a sült és rántott húsok tartoznak (szívesebben is ennének belőlük többször), illetve a sütemények és desszertek. Egyöntetűen nem kedvelt ételt/ ételcsoportot nem jelöltek meg, de kedveltségi listájukat a fózelékek és az egyszerü levesek zárták, amelyekból kevesebbszer is szeretnének fogyasztani. A pedagógusok egészségesebb ételcsoportokat preferáltak (halak, párolt, grillezett, rántott zöldségek) továbbá a rántott és a sült húsokat, és többször ennének halakat, sült húst és húsos leveseket. Kevésbé kedvelt éte- leik a tészta ételek, és az egyszerű levesek, de kevesebbszer ennének főzeléket és gabona köretet. Általában a pedagógusok magasabb értékelési szintet adtak egy-egy ételcsoportra, ezért az ételcsoportok majdnem felénél szignifikáns különbség adódik a diákok válaszaihoz képest. A tészta ételeket, és a süteményeket, desszerteket a diákok kedvelték szignifikánsan jobban.

$\mathrm{Az}$ ételek tulajdonságainak (íz, illat, táplálóság, hőmérséklet, szépen tálalás) diákok szerinti minősítése szignifikánsan alacsonyabb a pedagógusokénál. A higiéniával, az ételek egészségességével, és változatosságával mindkét csoport meg volt elégedve. Sajnos a diákétterem egyéni igényekhez való alkalmazkodása még nem megfelelő egyik csoport szerint sem.

\section{IRODALOMJEGYZÉK - REFERENCES}

Andersen, S. S. - Vassard, D. - Havn, L. N. - Damsgaard, C. T. - BiltoftJensen, A. - Holm, L.: Measuring the Impact of Classmates on Children's Liking of School Meals. Food Quality and Preference. 2016. 52 (1) 87-95.

ASTM: E 253 - 04 Standard Terminology Relating to Sensory Evaluation of Materials and Products, 2004.

ASTM: E 1958 - 98 Standard Guide for Sensory Claim Substantiation, 1998.

Bakacs M. - Martos É. - Schreiberné E. M. - Zentai A.: Országos iskolai menzakörkép 2013. Budapest 2014. URL: http://www.ogyei.gov.hu/dynamic/oeti_ forms/menza2013.pdf (letöltés dátuma: 2017.11.15.)

EACEA: European Commission/EACEA/ Eurydice, 2016. Compulsory Education in Europe - 2016/17. Eurydice Facts and Figures. Luxembourg: Publications Office of the European Union.

EMMI rendelet: 37/2014. (IV. 30.) a közétkeztetésre vonatkozó táplálkozásegészségügyi előírásokról. URL: http:// net.jogtar.hu/jr/gen/hjegy_doc. cgi?docid=a1400037.emm (letöltés ideje: 2017.01.05) 
EMMI rendelet: 36/2016. (XII. 8.) a közétkeztetésre vonatkozó táplálkozás-egészségügyi előírásokról szóló 37/2014. (IV. 30.) EMMI rendelet módosításáról. URL: http://net.jogtar.hu/jr/genhjegy_ doc.cgi?docid=A1600036.EMM\&timeshift $=$ fffffff $4 \&$ txtreferer $=00000001$. TXT. (letöltés ideje: 2017.01.05)

KSH: Népesség korév és nem szerint, január 1. (1980-). URL: http://www.ksh.hu/docs/ hun/xstadat/xstadat_eves/i_wdsdoo9. html (letöltés ideje: 2017.01.11.)

Lülfs-Baden, F. - Rojas-Méndez, J. I. Spiller, A.: Young Consumers' Evaluation of School Meals. Journal of International Food \& Agribusiness Marketing. 2008. 20 25-57.

Maietta, O. W. - Gorgitano, M. T.: School Meals and Pupil Satisfaction. Evidence from Italian Primary Schools. Food Policy. 2016. 62 41-55.

Noble, C. - Corney, M - Eves, A. Kipps, M. - Lumbers, M.: Food Choice and Secondary School Meals: the Nutritional Implications of Choices Based on Preference rather than Perceived Healthiness. International Journal of Hospitality Management. 2003. 22 197215.
OGYÉI: Iskolai közétkeztetés, Országos Gyógyszerészeti és Élelmezés-egészségügyi Intézet, 2016. URL: https://www.ogyei. gov.hu/kozetkeztetes/. (letöltés ideje: 2017.01.05)

Pagliarini, E. - Gabbiadini, N. - Ratti, S.: Consumer Testing with Children on Food Combinations for School Lunch. Food Quality and Preference. 2005. 16 (2) 131-138.

Popper, R.: Workshop Summary: Data Analysis Workshop: Getting the most out of just-about-right data. Food Quality and Preference. 2004. 15 (7-8) 891-899.

Tuorila, H. - Palmujoki, I. - Kytö, E. Törnwall, O. - Vehkalahti, K.: School Meal Acceptance Depends on the Dish, Student, and Context. Food Quality and Preference. 2015. 46 (1) 126-136. 


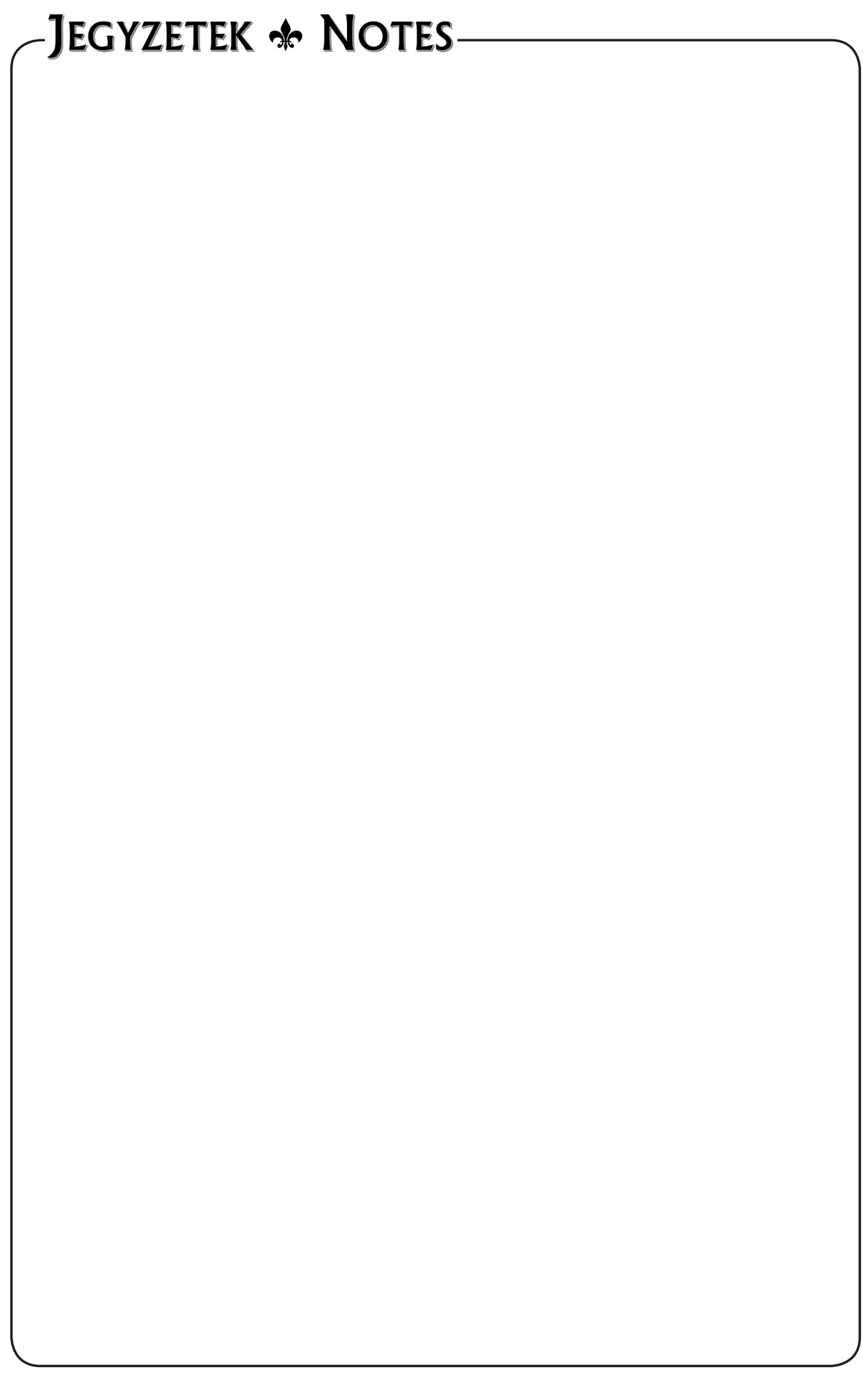

